\title{
ORGANIZATION-ECONOMIC MECHANISM FOR FINANCIAL ENSURING OF MARKETING ACTIVITIES OF SMALL ENGINEERING ENTERPRISES
}

\author{
Nestor SHPAK, Tamara KYRYLYCH, \\ National University "Lviv Polytechnic" ${ }^{1}$
}

\begin{abstract}
The article outlines the features of marketing activity of small engineering enterprises (SEE), the usefulness of their union for joint financing their marketing activity is substantiated. It is argued that the best form of marketing efforts integration and cooperation is an association as a contractual organization that does not interfere in the function of its members, but only consolidates marketing activity. Based on this study, the organization and economical mechanism of creation and functioning of SEE Marketing Association is proposed and the financial terms of cooperation between SEE and consulting firms are investigated to ensure fair and favorable agreements on the amount of membership fees for enterprises - the members of SEE Marketing Association. The features and directions of the use of membership fees are studies and the benefits of the creation of such associations are shown. It was established that the activity of the SSE Marketing Association will focus on consolidating marketing efforts and professional mutual assistance of its members to meet the marketing interests, improving marketing activities, market research, protection of marketing interests of association members, forecasting market situations, finding new sales channels
\end{abstract}

${ }^{1}$ Nestor SHPAK, Doctor of Sciences (Economics), Professor of the Chair of Management and International Business Undertakings, National University "Lviv Polytechnic";

5, Mytropolyta Andreya str., Lviv, 79046, Ukraine

+38-050-37-14-030

Email:dida_05@ukr.net

Tamara KYRYLYCH, post-graduate student, the Chair of Management and International Business Undertakings, National University "Lviv Polytechnic";

5, Mytropolyta Andreya str., Lviv, 79046, Ukraine

+38-066-657-52-99

Email: povstenkot@mail.ru 
and organizing activities in them, selecting the most appropriate sales channels, effective solutions to the problem of planning the distribution of products between sales channels of members of the Association, development of proposals concerning elimination of undisciplined intermediaries.

\section{KEY WORDS}

small engineering enterprise, marketing efforts consolidation, marketing benefits, business association, marketing association, organization-economic mechanism.

\section{INTRODUCTION}

In a dynamic environment, small enterprises have a lot of distinctive features (flexibility, mobility, easy adaptation to changing circumstances) that aid in developing and stirring up their marketing activities. However, due to a small number or complete lack of marketing staff, these activities are conducted not systematically and with invoking other organizations such as consulting firms. Collaboration with such firms requires considerable financial costs, which are often beyond small enterprise powers. Such conditions aid in the emergence of enterprise associations for consolidating their marketing efforts.

\section{LITERATURE REVIEW}

Small enterprises have been the subject of study of many researchers. The development of an effective mechanism of economic security of small enterprises was considered in the work [3], where the objective, strategic priorities and means of strengthening economic security of small enterprises were substantiated. In the collective monograph [12], the problem of identifying the factors which influence the efficiency of small enterprises was studied, some domestic problems of these enterprises were shown and the directions of steady development of small business were indicated. The researches $[6-9 ; 15]$ described the conditions of formation, development, management and support of small business. Financial aspects of small business functioning were studied in the work [1], where theoretical and applied problems of the formation and use of financial results of small enterprises, the management of their profits, expenses and income distribution were investigated. The authors of the monograph [14] studied the features of taxation of small businesses on the basis of alternatives. The aspects of cooperation and integration efforts of small enterprises received attention in $[2 ; 10]$. However, the specific character of associations of small enterprises in marketing is insufficiently studied and requires more substantial investigation. 
The goal of the article consists in substantiation of establishing the associations of small enterprises to consolidate their marketing efforts, to highlight the mechanism of financing and functioning of the Marketing Association of small engineering enterprises.

The main material. According to the Economic Code of Ukraine (Ch. 1, Art. 119), small engineering enterprises (SEE) may create voluntary unions that promote the joint solution of problems of their economic activity [5]. Such economic unions can be established as associations, corporations, consortiums, concerns, industrial and financial groups, associated enterprises, holding structures, etc. [11, p. 35-37]. The advantage of associations consists in the relative legal simplicity of their establishing, voluntary cooperation of enterprises of the same branch, the low level of centralization of management decisions, free entry to other business unions, the possibility of accumulation of membership fees for large-scale joint activities, etc. Contrary to other forms of enterprise unions, an association does not limit and does not interfere in business activities of its members. The authors of the work [11, p. 35] suggest a definition of an association as "a contractual union established for the purpose of permanent coordination of economic activities of enterprises which combine their efforts by centralization of one or more production and management functions, development of specialization and consolidation of manufacture, organization of joint ventures on the basis of consolidation of their financial and material resources to satisfy their most economic requirements."

Effective promotion of marketing activity of SEE requires considerable efforts and financial costs. To accumulate funds and combine efforts in the marketing field, we propose to create a Marketing Association of small engineering enterprises. Such a contract economic statutory association of small engineering enterprises is created for help in solving various problems of its members in the field of marketing. Cooperation of SEE allows them to increase their marketing activities by joint efforts in this field. Members of this Association pay fees which are used for market research, organization of joint promotional activities, joint advertising activities. The Association focuses on consolidation of marketing efforts and professional mutual aid in meeting marketing interests of its members, on increasing marketing activities, conducting market research, protecting marketing interests of association members, forecasting market situations, finding new sales channels and organizing activities in them, choosing the most appropriate sales channels, solving the problem of efficient planning of distribution of products between sales channels of Association members, elaborating the proposals for replacement of undisciplined intermediaries, etc.

We propose to create a governing body of SEE Marketing Association as follows: the General Meeting of SEE Marketing Association, the Council of SEE Marketing Association, the Board of Administration and the Auditing Commission consisting 
of representatives of the managing staff of the members. Such a structure of a governing body provides clearness and transparency of the receipt and use of membership fees, identifying priority areas of market research and directions of marketing activities, etc.

The practice of SEE work shows that for effective implementation of their marketing activities they should invoke outside organizations which can execute marketing tasks adequately and on a large scale, but this practice requires considerable marketing costs. Creating associations allows SEE, being its members, to implement their marketing activities effectively without overpaying to consulting firms. An association cannot interfere in the business activities of its members, but can be authorized to represent their interests [11].

High risk of losses causes the necessity of diversification of marketing activities concerning their resulting component - sales. This approach requires the analysis of a large number of sales channels to choose the most effective of them. Small business cannot solve this problem adequately and at the low costs without assistance. The way to consolidate marketing efforts of small engineering enterprises consists in creating a marketing association of such enterprises which provides integration and information interchange for selection of the most appropriate product distribution channels. For each enterprise such processes require considerable time and costs; in the case of cooperation on the basis of economic union the work done by the association is not duplicated, but its use by members of a marketing association. A marketing association provides that its members pay membership fees. The size of fees should be differentiated depending on the volume of annual turnover and should be directed to research conducted separately for each SEE, i.e., if an enterprise pays greater fees because its turnover is higher, then it can use more marketing information. If an enterprise does not conduct activities in the course of a year, it does not pay membership fees, but also cannot use marketing association service. If an enterprise is unprofitable and it does not pay membership fees, its participation in a marketing association of SEE stops or can be continued on a credit basis, provided that such a decision is made by the majority of members. The authors of the work [16] developed a method for planning optimal distribution of output between sales channels which is recommended to use as a tool for diversification of marketing activities during functioning of SEE marketing association. Its essence lies in analysis of sales channels, both actually and potentially used, individual study of characteristics and conditions of use of these channels by particular SEE. The activities of SEE Marketing Association focuses on joint solving a problem of optimal planning of production distribution between sales channels of the association members. The practice of small engineering enterprises shows that their products, as a rule, do not compete with each other, allowing them to combine marketing efforts without increased risk of information transmission to competitors. With the accumulation of funds in the SEE Marketing Association and joint use of them for special 
purposes, a member of the Association can receive marketing information more efficiently and about more sales channels, as well as conduct joint marketing activities, order printed products and monitor market situation involving smaller costs.

The practice of domestic and foreign consulting firms provides reasons enough to assert that there are different forms of payment for service of such firms: pay by the hour; undifferentiated fixed payment; percentage of the value of consulting object or result; combined payment [13, p. 59]. Firms providing consulting services in the domestic market (including such as "Macro Consulting Group", "ProConsult", LLC "Dreberis", marketing company "BBS", LLC "Andar Service", "West Ukrainian Information and Analytical Foundation"), as a rule, use the third (sometimes the fourth) payment option for their service. This choice is due to the fact that during the lengthy research the costs of service with pay by the hour is too high; fixed undifferentiated payment may lead to such a situation that financial results which can get an enterprise may be significantly lower than the value of money spent. A survey of a number of administrative personnel of SEE and of consulting firms shows that consulting firms get profit about $7-15 \%$ for the study of sales channels.

As it was shown above, small enterprises have a number of features that determine the characteristics of their marketing activities, in particular, they have small marketing staff or do not have it at all. This feature forces the need for cooperation of SEE with consulting companies or the creation of a public union - ESS Marketing Association, which exists owing to membership fees its participants (as a rule, $1 \%$ of annual turnover). This amount is justified by practice of cooperation between small enterprises and firms providing consulting service. Accordingly, the funds of each enterprise - a member of SEE Marketing Association - are taken into account separately for correct use of obtained joint marketing information and organizing joint marketing activities. These funds may be accumulated and spent not only on the study of sales channels, but also on other types of marketing activities such as printing services, special offers, etc. Creation of an association also allows avoiding duplication of research conducted by SEE. If one small enterprise in its marketing activities uses services of the $\langle\mathrm{P} »$, analyzing its work and cooperation conditions, and another small enterprise also wants to use services of the distributor «P», then the funds, which would be saved by combining efforts to study this distributor, can be directed to other types of marketing activities for both SEE.

On the basis of analysis of the literature [4, 17], the practice of activities of associations, consulting organizations and small engineering enterprises and using our own investigations, we present the mechanism of creation and functioning of ESS Marketing Association (Fig. 1). 


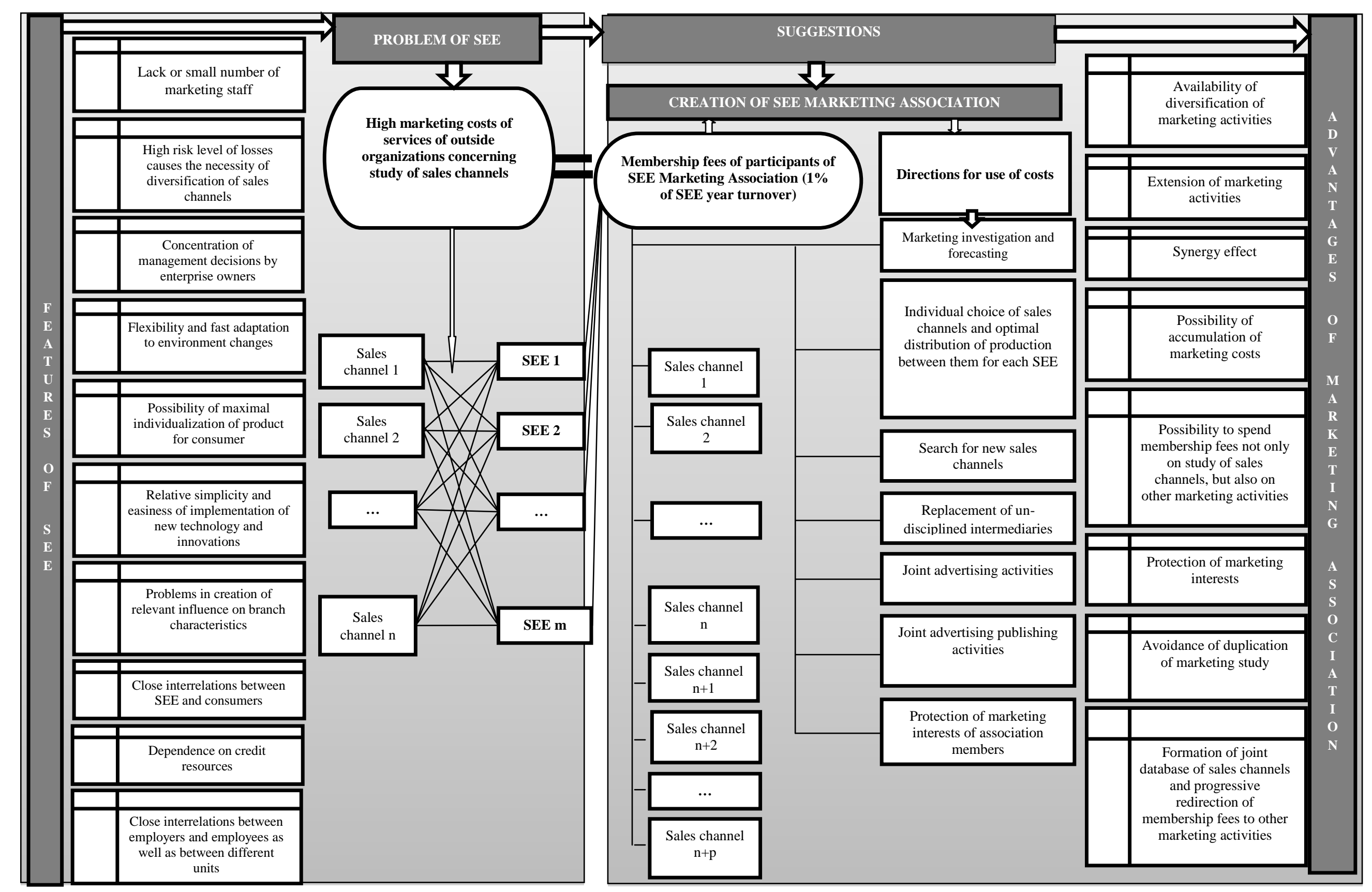

Fig. 1. Mechanism of creation and functioning of SEE Marketing Association 
Practice of small engineering enterprises shows that their marketing expenses do not exceed $5 \%$ of average annual turnover. This value was obtained by a survey of managers of domestic SEE. According to obtained data concerning five domestic SEE (private enterprise «Electrosvit», public joint-stock company «Crane Building Firm 'Strila'», limited liability company «Robitnya», private joint-stock company «Brotep-Eco», open joint-stock company «Autolyvmash»), money spent on marketing service from outside organizations concerning investigation of sales channels and promotion of production in them is presented in Table 1.

Table 1 The amount of annual marketing costs of small engineering enterprises, $\%$ of average annual turnover

\begin{tabular}{|l|c|c|c|c|c|}
\hline \multirow{2}{*}{ Name of the enterprises } & $\mathbf{2 0 1 0}$ & $\mathbf{2 0 1 1}$ & $\mathbf{2 0 1 2}$ & $\mathbf{2 0 1 3}$ & $\mathbf{2 0 1 4}$ \\
\hline LCC «Robitnya» & 2.5 & 3 & 3.7 & 4 & 3.9 \\
\hline PJSC «Brotep-Eco» & 1.1 & 1.8 & 2.5 & 2.34 & 2.7 \\
\hline OJSC «Autolyvmash» & 2.9 & 3.8 & 3.86 & 4 & 4.2 \\
\hline JSC «Crane Building Firm ‘Strila'» & 1.56 & 2.3 & 3.4 & 3.75 & 3.8 \\
\hline PE «Electrosvit» & 1.7 & 1.99 & 2 & 2.3 & 2.7 \\
\hline
\end{tabular}

Note: prepared by the authors on the basis of a survey of managers

Based on Fig. 1, it is recommended to set the membership fees of participants of SEE Marketing Association at $1 \%$ of annual turnover. To determine the economic benefit of creation of such an association we present a forecast of annual marketing costs of small engineering enterprises to 2017 inclusive. The results are shown in Fig. 2. 


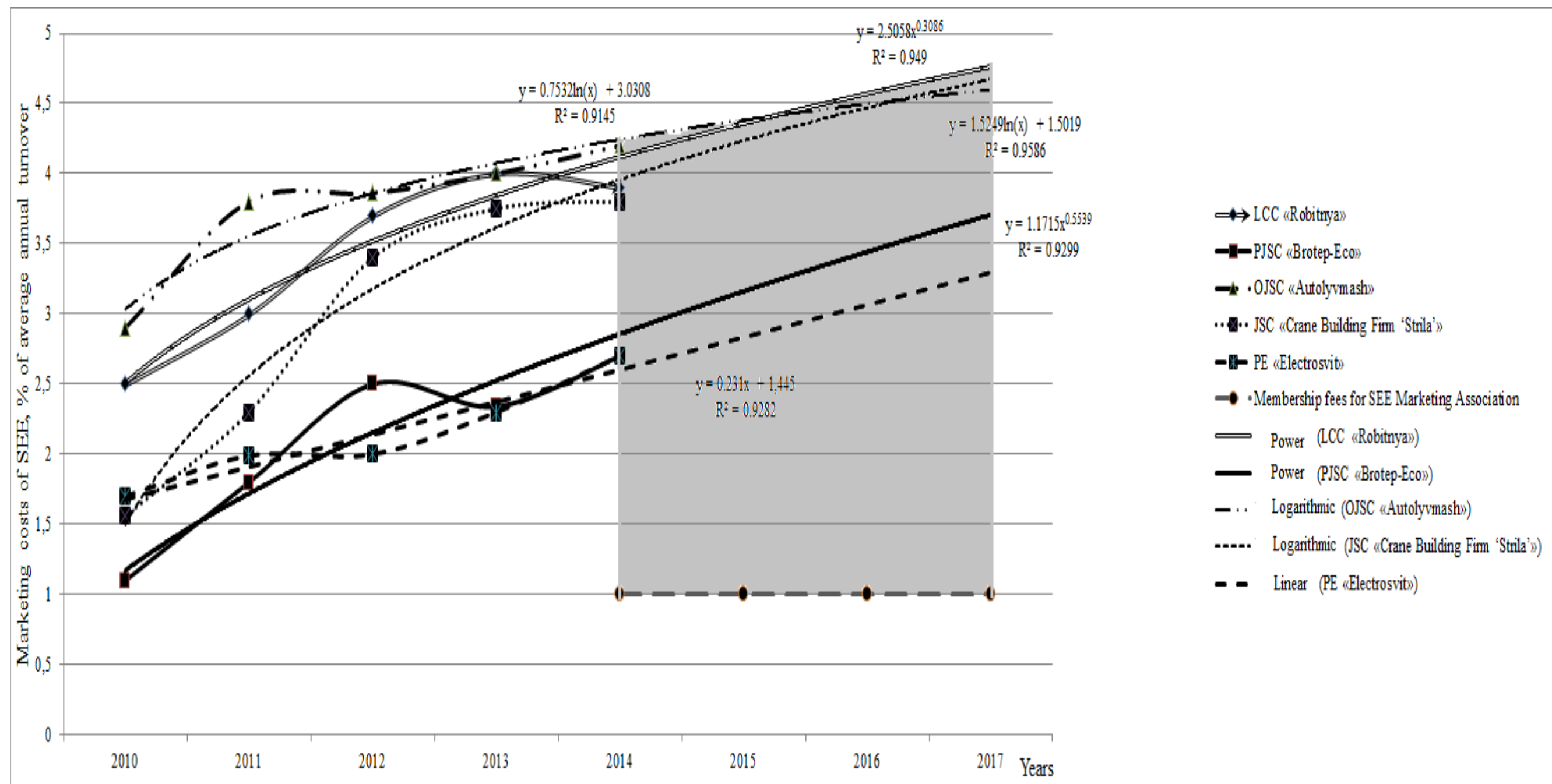

Fig. 2. Graphical interpretation of economic benefit of creating the SEE Marketing Association for several SEE. Legend to Fig. 2:

The value of forecasting cost efficiency of creating the SEE Marketing Association, \%. 
As it is seen from Fig. 2, average marketing costs of SEE are 2.5\% of the average annual turnover. Forecasting of marketing costs has been carried out using spreadsheet Excel. In particular, for LCC «Robitnya» the power model $\mathrm{y}=2.5058 \mathrm{x}^{0.03086}$ has been chosen with the value of approximation reliability $\mathrm{R}^{2}=0.949$ which testifies to correctness of the model. For example, in 2017 forecasting cost efficiency of joint financing marketing activities of LCC «Robitnya» will be $3.75 \%$ of average annual turnover of the enterprise: $4.75 \%$ (expected marketing costs) minus 1\% (membership fees for SEE Marketing Association). Forecasting of marketing costs for PJSC «Brotep-Eco» has been realized using the power model $\mathrm{y}=1.1715 \mathrm{x}^{0.5539}$ with $\mathrm{R}^{2}=0.9299$ testifying to correctness of a choice. For OJSC «Autolyvmash», forecasting has been carried out using the logarithmic model $\mathrm{y}=0.7532 \ln (\mathrm{x})+3.0308\left(\mathrm{R}^{2}=0.9145\right)$; for JSC «Crane Building Firm 'Strila'», the logarithmic model $\mathrm{y}=1.5249 \ln (\mathrm{x})+1.5019$ has also been used with $\mathrm{R}^{2}=0.9586$; for $\mathrm{PE}$ «Electrosvit», the linear trend $y=0.231 x+1.445$ has been used $\left(R^{2}=0.9282\right)$. According to forecasting of economic efficiency of joint financing marketing activities, such efficiency for PJSC «Brotep-Eco» in 2017 will be $3.68 \%$ of average annual turnover: $4.68 \%$ (expected marketing costs) minus $1 \%$ (membership fees for SEE Marketing Association). Similarly, we get 3.58\% for OJSC «Autolyvmash», 3.67\% for JSC «Crane Building Firm 'Strila'», and 3.35\% for PE «Electrosvit». The obtained results indicate that creation of SEE Marketing Association would be worthwhile. The forecasted membership fees can be held at $1 \%$ of average annual turnover due to new members.

Hence, the expected efficiency of SEE Marketing Association will grow every year, primarily due to expansion of the database concerning cooperation with sales channels of SEE and saving money by joint marketing research, which can be spent on other marketing activities, increasing the number of the association members, consolidation of marketing activities of the association members (synergy effect). Over time, association activities can be expanded by providing consulting service to other engineering industry companies and to firms from related branches.

\section{CONCLUSIONS AND PROSPECTS FOR FURTHER RESEARCH}

Our studies provide the bases for statement that small engineering enterprises should consolidate their efforts for qualitative, systematic and low-cost marketing research and thereby ensure them the opportunity to compete in the domestic market by the implementation of large-scale engineering marketing activities at a high level. Based on the examined characteristics of small engineering enterprises, we substantiate the necessity of creation of SEE Marketing Associations, which would ensure diversification of marketing activities. The mechanism of funding and functioning of an association is described; the benefits of membership of SEE in SEE Marketing Association are outlined. Further research will be related to the legal and regulatory aspects of establishing such associations, formulation a statute, election of a governing body, etc.

\section{REFERENCES}

Bilyk M. D., Bilyk T. O. Financial results of small enterprises activities: estimation and forecasting. - Kyiv: LLC "PanTot", 2012. - 280 p.

Bodrova I. I. Organizational-legal issues of Ukraine city councils' associations activity: Abstract of dissertation for the scientific candidate degree in jurisdiction, speciality 12.00.02 "Constitutional Law". - Jaroslav Mudryi National Law Academy of Ukraine, Kharkiv, 2002. 19 p. 
Vasyltsiv T. G., Voloshin, V. I., Gumenyuk A. M. Priorities and means of strengthening economic security of small and medium enterprises. - Lviv: Publishing House of Lviv Academy of Commerce, 2009. - 248 p.

Verba V. A., Reshetniak T. I. Organization of consulting activities. - Kyiv: Publishing House of Kyiv National Economic University, 2000. - 228 p.

The Economic Code of Ukraine: Adopted by the Verkhovna Rada of Ukraine on January 16, 2003 // Verkhovna Rada Herald. - 2003. - Vol. 18, Vol. 19-20, Vol. 21-22, p. 144.

Dryga S. G. Formation of the effective mechanism in state regulating of small entrepreneurship in Ukraine. Abstract of Thesis for the Doctor of Economic Science Scientific Degree, speciality 08.00.03 - "Economy and National Economy Management". - Scientific and research economic institute of Ministry of Economy of Ukraine, Kyiv, 2010. - 37 p.

Kampo G. M. Regional small business development management (Materials of Zakarpattya region). Abstract of dissertation for the scientific candidate degree in economic sciences, speciality 08.00.05 - "Development of Productive Forces and Regional Economics". - Uzhgorod National University. - Uzhgorod, 2009. - 19 p.

Kolisnik O. V. Strategic management of small mechanical engineering enterprises in conditions of competitive environment: Abstract of dissertation for the scientific candidate degree in economic sciences, speciality 08.00.04 - "Economy and Management of Enterprises (by Kinds of Economic Activities)". - National Technical University "Kharkiv Polytechnic Institute". Kharkiv, 2010. $-21 \mathrm{p}$.

Korobka S. V. Small Business in Agriculture: Abstract of dissertation for the scientific candidate degree in economic sciences, speciality 08.00.04 - "Economy and Management of Enterprises (by Kinds of Economic Activities)". - Lviv National Agrarian University, Lviv, 2009. - 20 p.

Kostyrko I. G., Burak A. I. Cooperation and integration of small enterprises in agricultural sector: theory, methods, practice. - Lviv: Liga-Press, 2013. - 192 p.

Kuzmin O. Ye., Melnyk O. G. Fundamentals of Management: a textbook, 2nd ed. - Kyiv: "Akademvydav", 2007. - 464 p.

Problems and prospects of steady development of small and medium-sized businesses in Ukraine: collective monograph in 2 volumes: Vol. 2 / ed. K. F. Kovalchuk. - Dnipropetrovsk: IMA-Press, 2012. $-172 \mathrm{p}$.

Tokmakova N. O., Andriyanova M. V. Management-Consulting: an educational- methodical complex. - Moscow: Publishing House of Eurasian Open Institute, 2009. - 271 p.

Filippova S. V., Ananska M. O. The choice of tax system and organization of tax accounting by entities of small business - juridical persons on the basis of alternatives. -Donetsk: Publishing House "Knowledge" (Donetsk branch), 2013. - 120 p.

Chubaryeva L. I. Small business: theory, mechanisms of support formation and development: Abstract of dissertation for the scientific candidate degree in economic sciences, speciality 08. 00. 01 - "Economic Theory and History of Economic Thought". - Donetsk National University, Donetsk, 2008. - 21 p. 
Shpak N., Kyrylych T. Sales channels selection for small industrial enterprises based on qualitativequantitative characteristic criteria // ECONTECHMOD: an international quarterly journal on economics in technology, new technologies and modelling processes, 2013. Vol. 02, No. 4. - P. 79-88.

Wilkinson J. W. Body of Knowledge for Consultants, In: S.W. Barcus III and J. W. Wilkinson (eds.) Handbook of Management Consulting Services, 2nd Edition. - New York: McGraw-Hill, 1995. 